\title{
Hate Speech in Readers' Comments and the Challenge of Democratic CONSOLIDATION IN NIGERIA: A Critical Analysis
}

\author{
Joseph M. Lucas \\ Taraba State University, Nigeria \\ josephlucas928@gmail.com \\ Tordue Simon Targema \\ Taraba State University, Nigeria \\ torduesimon@gmail.com
}

\begin{abstract}
Hate speech is among the most significant communication issues that preoccupy the agenda of relevant governmental agencies and media analysts in contemporary Nigeria. It is an unfortunate phenomenon that manifests in the public sphere, and is fast threatening the fragile democracy which the country is struggling to consolidate. Against this backdrop, this study investigates the nature of readers' comments on online news sites in the country, their place within the context of hate speech rhetoric, and their implication on democratic consolidation in the country. Hinged on the Social Responsibility Theory, the study employs quantitative and qualitative content analytical methods to investigate the manifestation of hate speech in online readers' comments. From a sample of 250 comments ( $10 \%$ of the population) from ten stories on prominent online news platforms in Nigeria, findings reveal that, although quantitatively, positive comments dominate the study population, qualitatively, the trend of discussion is disturbing, as commentators employ the use of hate language, verbal assault, name calling, insults and derogatory words to describe subjects. To this end, the study concludes that readers need to exhibit a high sense of responsibility in the course of interaction on the online comments platforms. Where such responsibility is not self-enforced by commentators, news platforms should remove comments that contain venomous hate language in the interest of national unity, democracy and development.
\end{abstract}

Keywords: democratic consolidation, hate speech, Nigeria, readers' comments

\section{INTRODUCTION}

Hate speech has become one of the biggest obstacles to democratic consolidation in Nigeria. The rate at which it is being perpetuated by key actors in the political scene is alarming, 
and its effects diffuse into the entire political system, making it capable of jeopardizing the struggle to consolidate the fragile democracy in the country. Today, most media houses in the country have condescended so low, and have given into the temptation of carrying messages that contain hate and dangerous speech, against the codes of conduct that guide journalism practice in the country (Ibrahim, Pate, Pereira, Ya'u, Agbanyin \& Bagu, 2017).

Sensationalism and the drive to sell media content are among the major reasons that entice media organizations to deviate from prescribed codes, and engage in unethical practices such as dissemination of hate speech and fake news. This has, indeed, increased the task of monitoring and regulatory agencies in the country such as the Nigerian Broadcasting Commission (NBC) and the Nigerian Press Council (NPC) among others. Perhaps, the advent of the new media in the Nigerian politico-media landscape has accelerated the occurrence and manifestation of hate speech in the country.

This is due largely to the fact that the new media is a free-for-all terrain, a loose journalism endeavour with little or no regulation and monitoring mechanisms. This unlimited freedom that it offers makes it possible for every person, armed with the appropriate technology to disseminate uncensored content to the public (Suntai \& Targema 2017). The popularity, degree of acceptance and access to the new media is unparalleled by any other medium, and with the recent convergence of the other mainstream media of communication on the new media, it has assumed the status of the melting point of media platforms, thereby, giving a strong voice to users.

Hate speech on the new media platform, therefore, is a phenomenon that has farreaching effect in a society where a vast number of citizens are active users of its various platforms. Reader's comments sections of news sites have not helped matters in this respect too. Interactivity, a feature which is associated with them facilitates the spread of hate speech in the country, where commentators on news stories engage in the dissemination of hate speech and injurious statements. This has increased the enormity of the question regarding the new media and hate speech. In this study, we examine closely, the degree of manifestation of hate speech in online readers' comments, with the aim to interrogate the implication of the practice on democratic consolidation in Nigeria.

\section{CONTEXT}

Nigeria as a country is unique in its nature and composition. This uniqueness becomes glaring if one recalls that it is made up of over 180 million people, about 400 ethnic groups and two (or perhaps, three) major religions; dozens of political parties and 36 federating states, and other additional complex platforms of diversities (Pate \& Oso 2017). This diversity is largely a colonial creation, as Orngu (2014: 321) notes, that "British colonialism has been severally lampooned for forcefully creating the Nigerian state out of severally variegated ethnocultural units". Danaan (2017) gives a deeper reflection on the diversity that characterizes the Nigerian state. In his words,

Nigeria is pluralistic in terms of ethnic, regional and religious identities. The colonial government that amalgamated the country in 1914 was said to have paid low attention to the complex issues bordering on the rivalries among ethnic groups (Albert, 3013; Alabi, 2002; Albert, 2002; Alubo, 2009; Kukah, 1994; Okidu, 2011). As 
many social groups struggled for identity, each of which found expressions in the post-amalgamation regime, conflicts of varying dimensions-especially organized ethnic and religious violence-took the center stage (p. 75).

Pate and Oso (2017: 1) also reiterate this connection between diversity in Nigeria and constant communal conflicts when they note that "negatively, competitive tendencies and poor management of diversity issues have resulted in explosions that had violently rocked the basis of the country". Within this social context, therefore, hate speech has a damaging effect of souring relationships among the various groups that make up the polity. This becomes more serious a case when such hatred is based on unfounded sentiments and is openly expressed even on the mass media. Recently, research evidence indicates an increase, albeit, the unfortunate trend of hate speech on the mass media platforms in the country, where, for commercial and other reasons, the media allow individuals and groups to use the media space and spew hatred and vituperative utterances on others. Consequently, the public sphere is torn into the divides that characterize the country, and public debates conform to the status quo, where issues are approached from clandestine and sentimental points of view by individuals.

The coming of the new media into the country's media landscape has not helped matters in managing diversity induced conflicts, as well as the spread of hate and dangerous speech. If anything; it has worsened the situation, as Takwa (2017) corroborates, that:

The largely unregulated social media whose access is coming closer to the population on a daily basis, thanks to the availability of mobile apps and android phones is now an opportunity for people to conceal identities and express sentiments, hate statements and at times, insults that would have been censored in the traditional media outlets. These new media eschew the norms and ethics of reporting, and have largely contributed to deepening of societal cleavages. They have deeply ignored the sensitivities in society (p.11).

Within this context, therefore, readers' comments platforms which are highly unregulated present complex phenomena worthy of investigation. The basic question which is pertinent to interrogate, thus, is: to what extent do commentators behave responsibly on the platforms in the interest of democracy and national development? The whole gamut of this study hinges on this question, answer to which would help to ascertain the place of readers' comments avenues in democratic consolidation in the country.

\section{STATEMENT OF THE PROBLEM}

The new media technologies have facilitated interactivity and enhanced participation of citizens in the discussion of issues at the local, national and international levels. This portends a lot for democracy, a system of government that thrives on the principles of popular participation and diversity of views and opinions in the public sphere. One would expect that the potentials of the various platforms that the technologies harbour are tapped effectively in the interest of accountability that would help to entrench democratic ethos, as indeed, evidence has shown over the years in the usage of the platforms to report issues such as elections and conflicts in the country. 
However, the new media platforms generally are prone to abuse, and often times, the gravity of such abuses are enormous to the extent that they could undermine the frantic efforts towards consolidating the country's fragile democracy. Readers' comments platforms are typical examples of how the new media technologies facilitate and at the same time complicate the struggle to consolidate democracy in the country. They are, at the moment, largely unregulated, with the tendency of facilitating reactions and interactions among commentators on online news platforms.

At the same time, they facilitate the rapid spread of hate speech and verbal combat among commentators. These have thrived for years unchecked in the country. How well this has augured with the herculean task of democratic consolidation is a subject of serious research, hence the current study seeks to investigate the manifestation, nature and target of online comments, and what the pattern of interaction on the platforms portend for democratic consolidation in the country.

\section{RESEARCH OBJECTIVES AND QUESTIONS}

The aim of this study is to interrogate the nexus between readers' comments on online news platforms in Nigeria and the task of democratic consolidation in the country. The specific objectives include:

- To examine the nature of comments on online news platforms in Nigeria.

- To identify the targets of commentators on political issues raised on online news platforms in Nigeria.

- To demonstrate the connection between online readers' comments and the task of consolidating Nigeria's fragile democracy.

Arising from the objectives above, this study sets to provide answers to the following research questions:

- What is the nature of comments on online news platforms in Nigeria?

- Who/what are the targets of commentators on political issues raised on online news platforms in Nigeria?

- What is the connection between online readers' comments and democratic consolidation in Nigeria?

\section{READERS' COMMENTS, HATE SPEECH AND DEMOCRATIC CONSOLIDATION: INTERROGATING THE NEXUS}

Readers' comment as a concept is a phenomenon made possible by recent developments and improvements on the technology of communication. Information and communication technologies have made it easy for the audience to reply instantly to messages that are disseminated on news sites, a trend that has been in vogue in developed nations since the turn of the $21^{\text {st }}$ century, and recently spread to developing nations as well. Everett (2011: 108) observes prevalence of this trend when he notes that "the growing presence of technology 
lets consumers connect with newspapers in a way not previously possible. Newspapers' websites often allow users to comment on any article or repost it via social networks."

Today, national daily newspapers in Nigeria such as The Punch, This Day, Daily Trust, Vanguard News, The Nation, Desert Herald, Daily Independence, Tribune and Blueprint among a host of others have conspicuous online presence, the majority of which allow readers to leave comments under the stories they publish on their websites. Similarly, broadcast media stations in the country Such as the Nigerian Television Authority (NTA), Federal Radio Corporation of Nigeria (FRCN), African Independent Television (AIT), Channels Television, SliverBird, TV Continental (TVC) and Arewa 24 etc. also have online websites with the same feature. Online-based news sites such as Premium Times, Sahara Reporters, Naija.com, Pointblank, Scan News and Daily Post among a myriad of others also allow readers to actively participate in the content they share through the comment section. To this end, the practice of readers' comments has become a key feature of mass-mediated communication in Nigeria.

Hate speech has assumed the status of a national concern in contemporary Nigeria. In fact, many Nigerians were stunned at the sight of the banner headline in Guardian Nigeria, one of the leading national daily newspapers in the country on 1 March 2018, which reads "Hate speech offenders to die by hanging in Senate's new bill." The bill which seeks to establish the Independent Commission for Hate Speech that will enforce hate speech laws across the country and ensure the elimination of the menace among other responsibilities (Guardian Nigeria, March 1, 2018) serves to justify the worrisome status which hate speech has assumed in the country recently.

Omilusi (2017) describes hate speech as words of incitement and hatred against individuals based upon their identification with a certain social or demographic group. Stressing further, he notes that it may include, but is not limited to "speech that advocates, threatens, or encourages violent acts against a particular group, or expressions that foster a climate of prejudice and intolerance, which can lead to targeted attacks or persecution of that group...." Cohen-Amalgor (2011) as cited in Omilusi (2017) offers an extensive definition of hate speech, thus,

Hate speech is defined as bias-motivated, hostile, malicious speech aimed at a person or a group of people because of some of their actual or perceived innate characteristics. It expresses discriminatory, intimidating, disapproving, antagonistic, and/or prejudicial attitudes towards those characteristics, which include gender, race, religion, ethnicity, color, national origin, disability or sexual orientation. Hate speech is intended to injure, dehumanize, harass, intimidate, debase, degrade and victimize the targeted groups, and to foment insensitivity and brutality against them (p.165).

Hate speech is on the rise in Nigeria, and finds expressions in two major factors that nurture and sustain its continuous existence, namely politics and ethno-religious conflicts. Ethno-religious conflicts have become so pervasive, most of which are politically motivated (Orounye, 2012). The outcome of most of them is wide-scale violence that often results in scores of deaths, destruction of lives and property worth millions of naira, intimidation and displacements of residents etc. Outbreaks of these conflicts often open the window for dissemination of injurious, hate, dangerous and vituperative speeches that have the capacity 
of accelerating the conflicts. Readers' comments present the avenues where such hate is openly expressed when issues of serious national concern are open for discussion in the public sphere, and demonize those with contrary views. Dauda, Abubakar and Lawan (2017) who investigate the pattern of interaction of commentators on the Boko Haram insurgency in Nigeria decry the prevalence of hate speech on the platform, in their words:

It is also worrying that the discourse use abusive and derogatory terms... the magnitude and the impact of the ubiquitously vituperative and vitriolic comments in some of the discourses of the Boko Haram insurgency observed can further escalate conflicts and create more 'monsters'. This conclusion is drawn within the conclusion that Nigeria is already overwhelmed with several challenges and does not need the spread of venomous ideologies to further aggravate her situation (p. 267).

The story at the political front is not different from this. Readers' comments provide the opportunity for readers to contribute to discussions on political matters. This opportunity is a unique one and benefits the practice of participatory democracy immensely. However, a careful observation reveals a pattern that is not only worrisome, but capable of overheating the political space, and by extension, the entire polity. Jibril and Targema (2017) examine the nature of online readers' comments in Nigeria vis-à-vis the national unity question, with reference to how readers reacted to President Muhammadu Buhari's maiden media chat, held on 30 December 2015, and discover an alarming prevalence of negative and injurious comments that qualify as hate speech. They conclude, based on the findings, that:

...the way readers were polarized along regional lines in their comments, posting negative and injurious comments, has the capability of reducing the platform into a chaotic and indiscreet battlefield where readers engage in war of words, which portends nothing good for the unity of the country. This can consequently affect more, the already epileptic unity of the country. Given the nature of the readers' comments that the presidential media chat received on the online news sites, this paper submits that the platform has the potentials of intensifying the divides that characterize the Nigerian state. The realization of the much desired unity in diversity in the country via this platform is not only far from reality, but also signals a cataclysmic danger to peaceful coexistence (p.190).

Democratic consolidation as used in this study represents meaningful effort(s) to unite the various ethnic groups that make up the polity and pursue a common course that will benefit the country's fragile and budding democracy. The struggle to enthrone democratic rule in the country, from independence in 1960 to date, has not been an easy one to the key stakeholders involved in the struggle, as Lucas and Targema (2017) observe. After two unsuccessful attempts to practice a democratic system of government in the country, the tide swung around, and in 1999, democratic rule was reinstated.

No doubt, the current democratic experiment in the country is the longest ever, spanning over a period of about eighteen years. The journey so far, however, is full of ups and downs, with several forces at work in the attempt to thwart all efforts to stabilize the system and drive home, the dividends to the masses (Lucas \& Targema 2017). Jega (2010:18) enumerates some of the most pressing challenges that constitute cogs in the wheel of democratic 
consolidation in the country to include a weak electoral system marred by malpractices, pervasive existence of prebendalism and patrimonialism, or what is termed as politics of godfatherism, endemic corruption, politics of exclusion that limits popular participation, poor infrastructural development, weak and porous judiciary and heavy concentration of power and state resources at the center among a myriad of many other obstacles that keep the cub democracy in a deadlock, thereby hindering good fruits to come out of it.

In the midst of all these shortcomings, we conceptualize democratic consolidation in this study, within the Nigerian socio-political milieu, as efforts to overcome the myriad of obstacles that stand on the path to sustainable democracy in the country, so that a healthy political order that is free of all the existing evils will be evolved to enable the key actors at the political scene drive home, the dividends of democracy to the masses. This is a big question that demands as a prerequisite, unity and harmony among the masses to form a formidable electorate that will keep the ruling class on her toes to be up-and-doing in the discharge of its responsibilities. In this guise, the major contention of the study is that democratic consolidation can only be attained if the masses eschew the spread of hate speech on the media space and readers' comments sections of news sites to enable them meaningfully discuss political issues in the country. How well this is done is the main motivation for the study.

\section{SOCIAL RESPONSIBILITY: A THEORETICAL FRAMEWORK FOR ANALYSIS}

The very nature of social responsibility theory suggests that it is most suitable for explaining the operational mode of journalists working with the traditional or mainstream media, and how the media operate within a given socio-political setting. From this background, the theory falls short in addressing issues which the new media and its concomitant communication avenues have raised in recent times. However, this study overlooks this inclination and explores the tenets of the theory that connects to the question of media practitioners (whether on the mainstream or new media), evolving a decent communication culture that benefits society amidst unlimited freedom of operation.

Social responsibility theory draws the attention of journalists (and by extension, the audience to whom technology has conferred the status of content creators) to the fact that they have freedom attached with the responsibility to the society (Littlejohn \& Foss, 2009; Suntai \& Targema, 2017). According to Bitner (1989), the theory originates from the United States of America. By the turn of the twentieth century, the printed press had been through the era of yellow journalism (a kind of journalism characterized by reckless reporting and unethical practice). Prior to this era, the press, through the efforts of freedom fighters such as John Milton, John Erskine, Thomas Jefferson and John Stuart Mill attained some considerable degree of freedom to operate without restrictions (formal/informal, constitutional or otherwise) in place (Sambe 2008).

There was, thus, a great need for self-moderation by journalists who were already abusing the excessive freedom. The social responsibility theory, thus, came on board. Central to the core assumptions of the theory is the fact that the press has the right to criticize government and institutions, but also has certain basic responsibilities to maintain the stability of society (Suntai \& Targema 2017). Online media platforms have provided the basis to expand the tenets of the theory to include the audiences as well, who have assumed the status of reporters or journalists. With the rise of public and citizen journalism, there is 
a need to extend the assumptions of the theory to the masses as well. Online readers who comment on media content are also seen within this premise as creators of media content, as the comments, they make form the basis for subsequent discussion on the issues raised in the media. Many readers form opinions based on the pattern of comments that usually trail online news stories. It is within this framework that the study finds it pertinent to reinterrogate the social responsibility question, as it relates to the key terms of 'freedom' and 'responsibility' in the pattern of readers' interaction on online news sites in Nigeria.

\section{METHOD}

This study employs quantitative and qualitative content analytical methods. The reason for this combination is to avail the study with adequate data that will enable for an elaborate discussion of the issue at stake. Content analysis is a research method that allows the researcher to intimately engage with communication content.

Kerlinger (2000) defines content analysis as a method of studying and analyzing communication in a systematic, objective, and quantitative manner for the purpose of measuring variables. It is for this purpose that this study finds the method suitable.

The population of the study comprises 2,530 comments generated from ten stories on political and pressing national issues in Nigeria. The stories are purposively selected from national dailies in the country. The emphasis in selecting the stories is on their degree of topicality, their being considered as national issues by the researchers, and their ability to generate many comments among online readers. Systematic sampling technique has been adopted to sample $10 \%$ of the comments. This results in a sample of 253 comments. Each comment has been considered as a unit of analysis.

Comments have been grouped into two categories: positive and negative comments. Positive comments are constructive in nature and do not insult or attack subjects. These kinds of comments do not necessarily agree with views of other commentators, but express their disagreement constructively, devoid of insult, name calling and hate language. Negative comments, on the other hand, are comments that carry insulting messages, employ the use of offensive and abusive language to describe subjects (people, regions, religions, tribe or any other victim), employ name calling to refer to subjects, and use stereotypes and pejorative adjectives to describe subjects. Negative comments possess most of the attributes of speech acts that are considered as hate speech.

Quantitative and qualitative methods of analysis aid the presentation and discussion of data in the study, while both manifest and latent meanings have been coded for analysis. The study encounters two major limitations: first, most of the online news sites have no comments under their stories, as readers' mostly comment when stories are shared on the Facebook pages of such news sites. This mandates the researchers to source for the comments on Facebook pages instead of the official websites of the news platforms, a practice that is more complicated than accessing the comments directly from the websites of the news platforms. Second, posts on the Facebook pages of the news sites get extremely difficult to search for as they get older each passing minute. Newer posts emerge frequently, making it difficult, and sometimes, impossible to access posts that are older than two days. 


\section{FINDINGS AND DISCUSSION}

Readers' comments have become the in-thing in the Nigerian media landscape. The abovedescribed procedure yields adequate data for analysis and discussion. It is, however, observed that some news sites attract readers' comments more than others. Sahara Reporters and Premium Times which are basically online news platforms with no offline (print) versions have the highest number of comments on their stories. Other news platforms that have both print and online versions also attract readers' comments, though relatively lower than the former. Table one below presents the distribution of comments that serve as the sampling frame for the study across the various news sites considered in the study.

\section{Table 1: Distribution of comments on the various news sites considered in the study}

\begin{tabular}{|c|c|c|c|c|}
\hline $\mathrm{S} / \mathrm{N}$ & $\begin{array}{l}\text { News site /Date } \\
\text { of publication }\end{array}$ & Title of selected story & $\begin{array}{l}\text { No. of } \\
\text { comments }\end{array}$ & $\begin{array}{l}\text { Sampled } \\
\text { comments }\end{array}$ \\
\hline 1 & $\begin{array}{l}\text { Sahara Reporters } \\
07 / 03 / 2018\end{array}$ & $\begin{array}{l}\text { Nigeria to support Ghana in fight } \\
\text { against corruption- Buhari }\end{array}$ & 867 & 87 \\
\hline 2 & $\begin{array}{l}\text { Sahara Reporters } \\
07 / 03 / 2018\end{array}$ & $\begin{array}{l}\text { INEC confirms registration of ineligible } \\
\text { persons in Taraba }\end{array}$ & 159 & 16 \\
\hline 3 & $\begin{array}{l}\text { Premium Times } \\
\text { 07/03/2018 }\end{array}$ & $\begin{array}{l}\text { Buhari fails to greet Obasanjo on } 81^{\text {st }} \\
\text { birthday }\end{array}$ & 350 & 35 \\
\hline 4 & $\begin{array}{l}\text { Premium Times } \\
\text { 07/03/2018 }\end{array}$ & $\begin{array}{l}\text { 2019: } 22 \text { other Nigerians eying Buhari's } \\
\text { job }\end{array}$ & 88 & 9 \\
\hline 5 & $\begin{array}{l}\text { Vanguard News } \\
07 / 03 / 2018\end{array}$ & $\begin{array}{l}\text { Show example in your country before } \\
\text { promising to fight corruption in } \\
\text { Ghana- Ben Bruce }\end{array}$ & 286 & 29 \\
\hline 6 & $\begin{array}{l}\text { Vanguard News } \\
07 / 03 / 2018\end{array}$ & $\begin{array}{l}\text { Ghana has nothing to fear, Nigeria will } \\
\text { help them fight against corruption }\end{array}$ & 129 & 13 \\
\hline 7 & $\begin{array}{l}\text { Guardian Nigeria } \\
07 / 03 / 2018\end{array}$ & $\begin{array}{l}\text { Kwankwaso risks expulsion for } \\
\text { shunning Tinubu's invitation }\end{array}$ & 234 & 23 \\
\hline 8 & $\begin{array}{l}\text { Guardian Nigeria } \\
07 / 03 / 2018\end{array}$ & $\begin{array}{l}\text { Death toll hits } 26 \text { in fresh Benue } \\
\text { herdsmen attack }\end{array}$ & 201 & 20 \\
\hline 9 & $\begin{array}{l}\text { Daily Trust } \\
\text { 07/03/2018 }\end{array}$ & $\begin{array}{l}\text { Buhari has no option but to seek re- } \\
\text { election- campaign organization }\end{array}$ & 66 & 6 \\
\hline \multirow[t]{2}{*}{10} & $\begin{array}{l}\text { Daily Trust } \\
07 / 03 / 2018\end{array}$ & $\begin{array}{l}\text { Nigerian senate may veto Buhari over } \\
\text { peace corps bill }\end{array}$ & 150 & 15 \\
\hline & Total & & 2,530 & 253 \\
\hline
\end{tabular}

Source: Fieldwork, 2018

Stories in the table above present the topical issues that have occupied the media space in the country within the study period. First on the array is President Muhammadu Buhari's speech at the occasion of Ghana's $61^{\text {st }}$ independence anniversary, where he promised to help the country in the fight against corruption. To take a step back into recent Nigerian history, 
President Muhammadu Buhari anchored his 2015 presidential election campaign (which he eventually won after three previous unsuccessful attempts) on three key issues: security, fight against corruption (which had almost become a national culture in the country), and economic revitalization. The prosecution of the war against corruption, three years after the administration came on board, however, is greeted with a lot of controversies, as many view the fight to be one-sided, targeting only people from the opposition camp.

This position has been worsened by the involvement of key actors in the administration such as the sacked Secretary to the Government of the Federation (SGF), Mr. David Babachir Lawal, the Minister of Justice and Attorney General of the Federation Mr. Abubakar Malami in corruption-related cases, and the administration's double-standard approach in dealing with the cases. More so, the recent rating by transparency international that has dropped Nigeria from the $136^{\text {th }}$ position to $148^{\text {th }}$ has not augured well will the President's acclaimed fight against corruption in the country. On this note, President Buhari's pledge to support Ghana in their fight against corruption generated reactions of all kinds among Nigerian online readers.

Underage voter registration is also among the issues that generate the interest of online readers. It is an unfortunate trend that befalls the country's electoral system, and is threatening to undermine the credibility of the electoral body in the country, the Independent National Electoral Commission (INEC) in the build-up to the 2019 general elections. Another issue that preoccupies online readers' attention is the failure of President Buhari to congratulate former president Olusegun Obasanjo on his $81^{\text {st }}$ birthday. This is against the previous experience, and ordinarily, wouldn't have been an issue, safe for the fact that the former president recently wrote an open letter to President Buhari, advising him not to seek re-election, and called for a Coalition for Nigeria that would help to steer the country to the path of progress (Obasanjo 2018). This act tends to sour the relationship between the two national figures; hence, failure to congratulate the former president on his new age generates interest of online readers.

Premium Times report that 22 Nigerians eying President Buhari's seat come 2019 also stimulates reactions among online readers, who discussed the possibility of the incumbent president getting re-elected on one hand, or getting overthrown on the other. Herdsmen attack on farming communities in the country also constitutes one of the most discussed issues on the online news sites, as the killings continue by the day, and defy all solutions to tame them, while death toll and destruction of property keep increasing.

The political squabble between Kano state Governor Abdullahi Umar Ganduje and his former boss, Senator Rabiu Musa Kwankwaso which gains momentum recently, and the face-off between president Buhari and the National Assembly with regards to Presidential assent to the bill to establish Peace Corps in the country are among the issues that have preoccupied the attention of online commentators in the country within the study period.

\section{Nature of Comments on Online News Sites in Nigeria}

It is pertinent at this juncture, to take a look at the nature of comments that trend on Nigerian online news sites when issues of national concern are raised. Below is a graphic representation of comments sampled in the study based on their nature. 


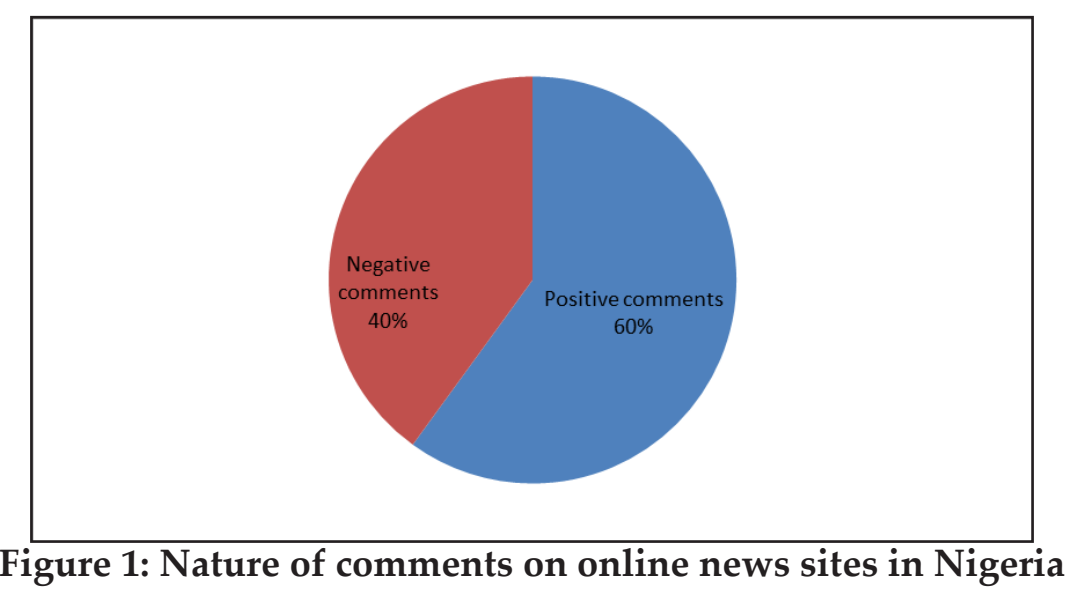

Source: Fieldwork, 2018

Figure one above presents the nature of comments on Nigerian news sites. An overwhelming $60 \%$ of these comments are positive. We argue that this will facilitate a healthy discussion of political matters on the platforms in the interest of democracy. Positive comments are constructive in nature. Although they sometimes address personalities (as we will depict later), most often, they address issues. This pattern of discussion is worth recommending. Most often, positive commentators do not agree with other commentators, but such disagreement is expressed in a matured manner, devoid of insult, name-calling and abusive words that constitute the gamut of hate speech. For instance, a commentator on Buhari's pledge to help Ghana in the fight against corruption wrotes as follows:

That's why President Buhari becomes champion on war against corruption in Africa. From Nigeria, all corrupt people will have sleepless night since Buhari decide to extend his war against corruption to Ghana.

Accordingly, this kind of comments set the tone for the positive and progressive discussion of issues on the platform. Another example of a positive comment on the same story is presented below:

Nigerians are busy castigating Buhari's government, but those who know who is Buhari are happy to have him as their chief guest to deliver a speech. When are we Nigerians going to learn a lesson...? Up PMB

Positive comments are found across the stories sampled, and constitute $60 \%$ of the total sampled comments. Regrettably, negative comments also constitute a large chunk of the comments generated by readers as they discuss issues raised on the various news sites. Negative comments employ all sorts of mechanisms - name-calling, verbal assault/terror, insulting and abusive words, stereotypes etc. to demonize, antagonize or demean the target. Such comments have the ability to steer discussion on the platforms off the progressive path to a retrogressive trend that diminishes the potentials of the platforms. For instance, a commentator on the story-show example in your country before promising to fight corruption in Ghana-Ben Bruce, on Vanguard News website writes: 
You are a foolish man Ben. PMB fight corruption than any past leader but you and your cohorts are fighting back in different dimensions. God will judge all of you idiots.

Similarly, another commentator on the same story writes:

As stupid as Fayose, go and steal our money and see if you can go away with it. NO MORE LOOTING AGAIN. AHAHAHAHAHAHAHAHAHAHAHAHAHН

Expectedly, such comments attract negative replies and counter comments from subsequent commentators, and have the ability to detract commentators to derail from the main issues that are being discussed on the platforms. Negative comments often set the stage for virtual combat or war of words among commentators. Worrisome is the high level of comments that contain hate speech in this category of comments. Accordingly, 47 comments (19\%) of the sampled comments contain insults. We argue that this trend is not healthy for democratic consolidation in a country characterized by several divisive tendencies.

\section{Target of Commentators on the Platform}

Another issue worthy of note is the target of commentators on the platform. Targets here are categorized into issues, individuals/personalities, regions/religions, and groups. The distribution of comments belonging to these categories is contained in the chart below:

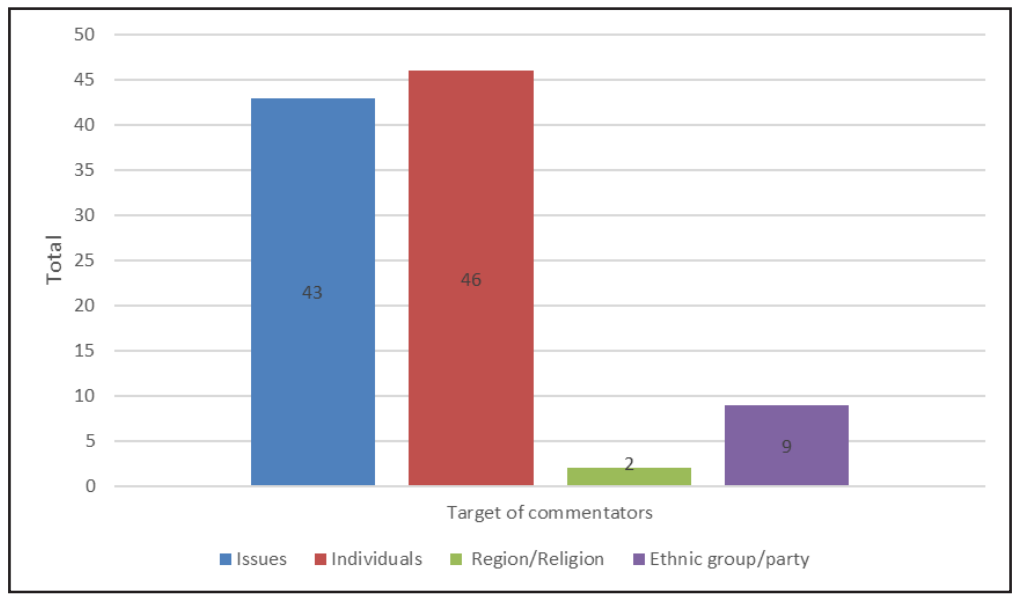

Source: Fieldwork, 2018

Figure 2: Target of commentators

Most positive comments address issues. They speak to the issue at stake, and not the personalities or individuals involved in the issue. Such comments help to guide the direction of discussion and bring up salient perspectives to the issue raised in the news. For instance, a commentator on the story entitled "INEC confirms registration of ineligible persons in Taraba" published on the news site of Sahara Reporters on the 7 March 2018 wrotes:

INEC is indicting Taraba voters register because it is a PDP state and cleared Kano where INEC staffs were threatened to death if they don't register underage children. What a country. 
Such comments constitute $43 \%$ of the total sampled comments. Comments targeted at individuals, on the other hand, do not discuss issues, but personalities. Such comments are often negative in nature and are aimed at demeaning the personality which they attack. Although few of the comments targeted at individuals are positive in nature, a vast majority of comments in this category are negative and contain some varying degrees of hate speeches. For instance, the following comments are among a myriad of others on the story, namely "Ghana has nothing to fear, Nigeria will help them fight against corruption", published on the news site of Vanguard News on the 7March 2018:

Buhari shame no dey your eye...u nava arrange ur country very well but $\mathrm{u}$ dey enjoy how Ghana dey celebrates der own nation without taking light. May God help $\mathrm{u}$ and reverse good leadership in $\mathrm{u}$.

Buhari has mental problem. His brain is not working well again.

Also, on the story of "INEC confirms registration of ineligible persons in Taraba" published on the news site of Sahara Reporters on the 7 March 2018, a commentator wrote:

Wah of kano, sokoto, zamfara, katsina and d rest!? Even goats, cows and rams have PVC. We know ur tricks Mr inec chairman, Idiot

Similarly, replying to a comment on the story, "Death toll hits 26 in fresh Benue herdsmen" attack, published in Guardian Nigeria on the 7 March 2018, a commentator wrote,

Idiot how I wish you are seeing what is happening in Benue, we are after farm and again human life is much more important than that of politics, so be mindful of ur words against the Benue people.

Sadly too, other commentators target their comments on regions or religions. A typical example of these kinds of comments is a comment on the story "2019: 22 other Nigerians eying Buhari's job", published on Premium Times news site, where the commentator wrotes:

Terrorist northerners shameless people cow brain

Another commentator on the same story refers to Igbo people of the south-eastern region as follows:

Useless animals, this hatred will not take away ur pains of being rejected and sidelined to contribute in national development. U r still that common slaves.

A commentator on the story "Show example in your country before promising to fight corruption in Ghana - Ben Bruce" published on the news site of Vanguard News, 7 March 2018 replies another commentator, making reference to the Shiite Islamic group as follows:

hahaha! Shiite guy. don't worry buhari would soon release your oga from army custody. but be inform that pmb will rule again GOD willing. 
The last category of comments reviewed under this category targets ethnic group, political parties or organizations. Below are few selected examples from the sample:

PDPIGS (referring to the politica party- PDP) show your candidate, anybody want to contest against Mai gaskiya will have a lot of work, with his unconditional love the game is up and non of the criminals can stop Pmb from returning God's will.

Yoruba pigs will always support Buhari chameleons

Foolish Hausa bloodsucker, like father like son!, you're better than Buhari, you're a bloodsucker, Buhari is a vampire.

Such is the direction of comments on Nigerian news sites that makes commentators derail from the issues at stake, and attack personalities, groups, regions and religions as well as tribes. It is obvious from the discussion above, that hate speech has assumed a central position in the discussion of political issues on online news platforms, the implication of which has far-reaching effects on the struggle to consolidate the fragile democracy in the country.

\section{CONCLUSION AND RECOMMENDATIONS}

Although quantitatively, the study reveals high evidence of positive comments on online news platforms, a qualitative discourse of the nature of comments reveals a damaging trend of negative comments which float freely platforms. Commentators use the platforms to spew hatred, verbally assault, attack and demonize others. We argue that, should this trend continue unchecked, it will diminish the benefits which the platforms have to offer for the healthy discourse of political issues, and indeed, other related issues in the interest of democracy.

It is against this backdrop that we suggest the re-awakening of the social responsibility rhetoric in the media industry. Yes, people must be free to express their views on matters of national concern without restrictions, but such a freedom must be accompanied with responsibility, and where it is grossly abused, the study recommends that online news platforms should monitor and remove comments that have the potentials of adversely affecting the unity of the nation. This way, the platforms can be effectively utilized for healthy political discourse that will serve to consolidate the budding democracy in the country.

To further researchers, the study recommends that there is need to explore how effective the platforms are in managing the myriad of ethno-religious conflicts that have engulfed the nation. Similarly, there is a need to investigate how the platforms have helped to ensure gender inclusiveness and representation within the public sphere. This research effort should tilt towards unravelling how the online readers' comments platforms have empowered women to participate actively in public debates, and make meaningful contributions to issues that are within the public domain. Such research exploits will help to ascertain the place of online readers' comments to the advancement of contemporary society. 


\section{REFERENCES}

Bitner, J. (1989). Mass communication: an introduction. Prentice Hall: New Jersey

Danaan, G.N. (2017). Reporting diversity: towards understanding Nigeria's ethnic and religious conflict through the mediatisation theory. In U. Pate \& L. Oso (Eds.), Multiculturalism, diversity and reporting conflict in Nigeria. (pp. 75-95). Ibadan: Evans Brothers (Nigeria Publishers) Limited.

Dauda, S., Abubakar, A.A. \& Lawan, A.K. (2017). Discursive devices, social media and conflict discourse in Nigeria. In U. Pate \& L. Oso (Eds.), Multiculturalism, diversity and reporting conflict in Nigeria. (pp. 250-271). Ibadan: Evans Brothers Publishers Limited.

Everett, C.E. (2011). Transformation of newspapers in the technology era. The Elon Journal of Undergraduate Research in Communication Studies, 2 (2): 23-34.

Ibrahim, I., Pate, U., Pereira, C., Ya'u, Y.Z., Agbanyin, B.O. \& Bagu, C. (2017). The escalation of hate and dangerous speech in the build up to the 2015 election and the imperative of strengthening the broadcasting code. A paper presented at the NBC Stakeholders Forum on Political Broadcasts, Chilla Luxury Suites, Kano. 26 October.

Jega, A.M. (2010). A decade of transition to democracy, 1999-2009: Reflections on Nigeria's fourth republic. In S. T. Ngarka, \& T. Wuam (Eds.), The Fourth Republic in Nigeria: A Decade of Democratization Reviewed, (pp.12-21). Makurdi: Aboki Publishers.

Jibril, A. \& Targema T. S. (2017). Online readers' comments and national unity. In AyedunAluma, (Ed.), Digital media, new order? Emergent practices in the Nigerian media environment, ACSPN Book Series 2, pp.170-193, Canada: Canada University Press.

Jimoh, A. M. \& Opara, G. (2018, March). Hate speech offenders to die by hanging in Senate's new bill. Guardian Nigeria, p. 1.

Kerlinger, F. N. (2000). Foundations of behavioral research (4th Ed.). New York: Holt, Rinehart $\&$ Winston.

Littlejohn, S.W. \& Foss, K.A. (2009). Encyclopedia of communication theory. New Delhi: SAGE

Lucas, J. M. \& Targema, T.S. (2017). Media-state relationship in democratic societies: an appraisal of the current Nigerian democratic experiment. The Nairobi Journal of Humanities and Social Sciences 1, (10): 28-42.

Obasanjo, O. (2018, January 26). The way out: a clarion call for coalition for Nigeria movement. Premium Times, p. 13.

Omilusi, M. (2017). From convenient hibernation to circumstantial desperation: hate speech, party political communication and the Nigeria's 2015 general elections. Brazilian Journal of African Studies, 2 (4): 160-183.

Orngu, C. S. (2014). Ethnicity and identity politics: challenges for Nigerian federalism. In V. Egwemi, T. Wuam \& C. S. Orngu (Eds.) Federalism, politics and minorities in Nigeria: Essays in honour of Professor G. N. Hembe, (pp. 321-332). Lagos: Bahiti and Dalila Publishers.

Orounye, E.D. (2012). The socio-economic impact of land resource conflict in Taraba State: A case study of Kona-Minda crisis in Northern Taraba. International Journal of Environmental Sciences, 1(2): 46-49.

Pate, U. \& Oso, L. (2017). Introduction. In U. Pate \& L. Oso (Eds.), Multiculturalism, diversity and reporting conflict in Nigeria. (pp. 1-7). Ibadan: Evans Brothers Publishers Limited.

Sambe, J.A. (2008). Introduction to mass communication practice in Nigeria. Ibadan: Spectrum Books. 
Suntai, D. I. \& Targema, T.S. (2017). New media and democracy in Nigeria: an appraisal of the opportunities and threats in the terrain. Brazilian Journal of African Studies, 2 (4): 198-209.

Takwa, Z. S. (2017). An overview on multiculturalism, diversity and reporting of conflict in Nigeria. In U. Pate \& L. Oso (Eds.), Multiculturalism, diversity and reporting conflict in Nigeria. (pp. 8-21). Ibadan: Evans Brothers (Nigeria Publishers) Limited.

Wimmer, D. \& Dominick, J. R. (2010). Mass media research: an introduction (9TH Ed.), Boston: Wadsworth, Cengage Learning. 